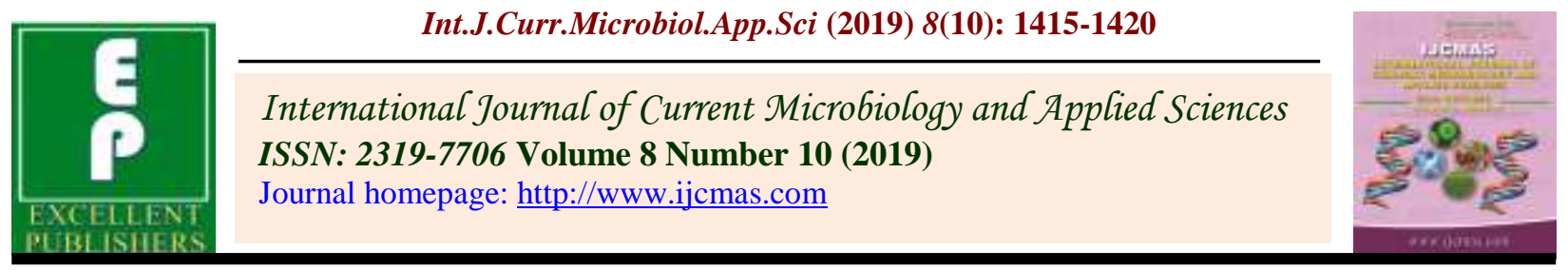

Original Research Article

https://doi.org/10.20546/ijcmas.2019.810.166

\title{
Genetic Polymorphism of MHC Class II DRB3 Gene in Salem Black Goats by PCR- RFLP
}

S. B. Thirunavukkarasu ${ }^{1}$, Pushpendra Kumar $^{1}$, Om Prakash ${ }^{1}$, Amit Kumar ${ }^{1}$, Nihar Ranjan Sahoo' ${ }^{1}$, G. V. P. P. S. Ravikumar ${ }^{1}$, Bharat Bhushan ${ }^{1}$, K. Ilayakumar ${ }^{1}$, V. Sharavanan ${ }^{2}$ and N. Nagarajan ${ }^{3}$

${ }^{1}$ Molecular Genetics Lab, Division of Animal Genetics, ICAR-Indian Veterinary Research Institute (IVRI), Izatnagar, Bareilly, Uttar Pradesh-243122, India

${ }^{2}$ Director of Animal Husbandry and Veterinary Services, Chennai- 600 006, India

${ }^{3}$ Veterinary Assistant Surgeon, Sheep Farm, Chinnasalem, Villupuram- 606 201, India

*Corresponding author

\section{A B S T R A C T}

Keywords

SNPs technique, PCR - RFLP, MHC class II DRB3, TaqI

Article Info

Accepted:

12 September 2019 Available Online: 10 October 2019
The highly polymorphic gene of the MHC is central molecule in immune system in recognition of pathogens and parasites. The purpose of this study was to study the polymorphism of CLA-DRB3 gene in Salem black goat using PCR-RFLP technique. A region of exon 2 encompassing 285 bp fragment of DRB 3 gene was amplified by polymerase chain reaction. The restriction digestion by TaqI revealed three genotypes AA (285 bp), AB $(285 / 163 / 122 \mathrm{bp})$ and BB (163/122 bp) with frequencies $0.220,0.490$ and 0.290 , respectively and two alleles $\mathrm{A}$ and $\mathrm{B}$ with frequencies 0.465 and 0.535 , respectively. The polymorphic information content (PIC) value and expected heterozygosity were 0.374 and 0.490 , respectively which were low in both cases. The present study showed polymorphic nature of MHC Class II DRB3 Gene in Salem black goats at this locus and the frequencies of heterozygote were greater than homozygote.

\section{Introduction}

Caprine MHC is located on chromosome number 23 also known as caprine lymphocyte antigen (CLA) or Goat lymphocyte antigen (GoLA) which has three subgroups, MHC Class I, MHC Class II, MHC Class III, among these the Class II molecule play a pivotal role in the initiation of the immune response by presenting exogenous antigens to helper $\mathrm{T}$ lymphocytes specially elicit the antibody production against the pathogen or parasites (Klein, 1986) and which is divided into two subtypes DQ and DR, which has been shown expressed similar that of cattle (BoLA) (Takada et al., 1998). 
Among these two subgroups, the DRB locus is the most polymorphic and considered functionally to be responsible for the differences among individuals in the immune response to infectious agents, hence received the greatest attention of research groups for association studies in sheep (Tizard, 2004; Dukkipati et al., 2006). The high degree polymorphism at MHC loci is intended to be an outcome of balancing selection at this locus (Garrigan and Hedrick, 2003). Characterization of entire MHC gene is difficult, due to large genomic size of; therefore studies have been conducted in part of fragment as per importance of different regions.

The exon 2 of caprine MHC class II DRB3 gene polymorphic variation of allele reported in Chinese indigenous goats(Li. M. H et al., 2006), Raeini Cashmere goats (Baghizadeh et al., 2009) and Rohilkhandi goats (Shrivastava et al., 2015) at different SNP loci.

In sheep, the polymorphism of DRB locus has been defined by using several PCR-based methods including sequence specific oligonucleotide probe analysis, single-strand conformational polymorphism (SSCP), RFLP analysis with identification using Southern blot analysis and cloning and sequencing (Nikbakht et al., 2009).

Genetic polymorphism study at MHC locus facilitates the identification of specific allelic variations that may be affecting disease resistance and susceptibility traits. Salem black goats are hardy with low overall mortality, innate resistance to the harsh climatic conditions prevailing in its original habitat. There is a lack of information on genetic characterization of Salem black goats at MHC loci. Therefore, current study was planned to estimate the polymorphism of the most critical regions of the MHC class II DRB3 gene in Salem blackgoats.

\section{Materials and Methods}

\section{Sample collection}

The study was undertaken at Molecular Genetics Laboratory, Division of Animal Genetics, Indian Veterinary Research Institute (IVRI), Izatnagar, Bareilly (UP). A total of 100 blood samples were collected from a randomly mating population of Salem black goats maintained at Government Sheep and Goat farm, Chinnasalem, Villupuram District of Tamilnadu, India.

\section{Sampling and analytical methods}

About $5 \mathrm{ml}$ of anticoagulated blood was collected under sterile conditions from the jugular vein of goats by using $2.7 \%$ EDTA. All the blood samples were kept in $-20^{\circ} \mathrm{C}$ till further processing for DNA extraction.

\section{Isolation of genomic DNA}

Genomic DNA was isolated from whole blood by phenol-chloroform extraction and ethanol precipitation method as per standard protocol (Sambrook and Russell, 2001).

\section{Locus under investigation}

The locus under investigation was selected from NCBI GenBank database. Two sequences with accession numbers KP888556 and KP888557 (Shrivastava et al., 2015) were utilized for the further study which was conducted to find out the polymorphism at MHC class II DRB gene in Rohilkhandi breed of goat. The SNP (C/G) atTaqI position at 122 bp position was chosen from 285 bp fragment.

Then, single cutter restriction enzyme (TaqI) was selected by using NEBcutter V2.0 online available software. The TaqI enzyme digests the 285 bp fragment of MHC class II gene and creates sticky ends at 122/124 bp position. 


\section{Polymerase Chain Reaction (PCR)}

To get the desired 285 bp fragment, PCR was performed using primers with the sequence of the forward and reverse primers were 5'-TAT CCC GTC TCT GCA GCA CAT TTC-3' and 5'-TCG CCG CTG CAC ACT GAA ACT CTC-3', respectively (Amills et al., 1990). The PCR reaction was performed in $25 \mu 1$ reaction mixture that included 10 pmol of each primer, $12.5 \mu \mathrm{l}$ of $2 \mathrm{X}$ PCR master mix (Thermo Scientific) and $1 \mu 1$ of 50 to $100 \mathrm{ng} / \mu \mathrm{l}$ of goat genomic DNA as a template. The PCR conditions includes initial denaturation at $95^{\circ} \mathrm{C}$ for 5 minutes followed by 40 cycles each of denaturation at $95^{\circ} \mathrm{C}$ for 1 minute, annealing at $59.5^{\circ} \mathrm{C}$ for 45 seconds, extension at $72^{\circ} \mathrm{C}$ for 1 minute and then a final extension at $72^{\circ} \mathrm{C}$ for 5 minutes. The $5 \mu \mathrm{l}$ PCR products were checked by $1.5 \%$ agarose gel electrophoresis in order to check the quality and specificity of PCR product using ethidium bromide staining. Finally, the gels were photographed under UV light with a gel documentation system (Syngene).

\section{Restriction enzyme digestion and electrophoresis}

About $10 \mu \mathrm{l}$ of PCR products were digested by restriction endonuclease (2U) with the appropriate buffer supplied with the enzyme and kept for overnight digestion at $65^{\circ} \mathrm{C}$ for TaqI (Thermo Scientific).The digested products were run on agarose gel from $2 \%$ as expected size of fragments with suitable DNA marker. Finally, the gels pictures were saved with a gel documentation system (Syngene gel doc system).

\section{Statistical Analysis}

After enzymatic digestion, the allelic and genotypic frequencies of the locus at CLADRB3 gene fragment were estimated by using PROC ALLELE procedure of SAS.9.3. Test for Hardy Weinberg equilibrium and neutrality ratios were done using POP GENE v 1.32 .

\section{Results and Discussion}

The quality of PCR amplified product of 285 bp MHC class II DRB 3 gene in Salem black goat was examined in agarose gel electrophorosis (Fig. 1). The digestion of PCR product by TaqI restriction enzymes showed $\mathrm{AA}, \mathrm{AB}, \mathrm{BB}$ genotypes and presence of two alleles (Fig. 2). The allelic and genotypic frequency at marker loci TaqI is shown in Table 1. In Salem black goat population the genotypic frequencies of TaqI locus were found to be $0.220,0.490$ and 0.290 for AA (285/285 bp), AB (285/162/123 bp) and BB $(162 / 123$ bp) genotypes, respectively. The frequency of heterozygote was greater than homozygote. The frequency of $\mathrm{B}$ allele (0.535) was higher than A allele (0.465) (Table 1).

The loci showed a PIC value of 0.374 with heterozygosity values of 0.490 and the allelic diversity values were estimated to be 0.498 . The summary of markers in relation to Polymorphic Information Content (PIC), and test for HWE are given in Table 2. Test for HWE showed that population was significantly $(\mathrm{P}=0.023)$ deviating from $\mathrm{HW}$ equilibrium at this locus, this may be due to the use of less number of males for breeding purpose.

The presence of this TaqI site was associated with a TTC codon (Phe) at position $40^{\text {th }}$ while its absence was associated with a TAC codon (Tyr) at the same position (Amills et al., 1990).

The gene and genotypic frequencies of the present study are in concordance with the other reported studies (Shrivastava et al., 2015; Prakash Om et al., 2017). 
Table.1 Allelic and genotypic frequencies at TaqI locus

\begin{tabular}{|c|c|c|c|c|c|c|}
\hline Locus & Genotype & Count & Frequency & Allele & Count & frequency \\
\hline TaqI & AA & 22 & 0.220 & A & 93 & 0.465 \\
\hline & AB & 49 & 0.490 & B & 107 & 0.535 \\
\hline & BB & 29 & 0.290 & Total & $\mathbf{2 0 0}$ & $\mathbf{1}$ \\
\hline & Total & $\mathbf{1 0 0}$ & $\mathbf{1}$ & & & \\
\hline
\end{tabular}

Table.2 Chi square test values for HWE at TaqI locus

\begin{tabular}{|c|c|c|c|c|c|c|c|c|c|}
\hline Locus & Count & $\begin{array}{c}\text { No of } \\
\text { alleles }\end{array}$ & PIC & Heterozygosity & $\begin{array}{c}\text { Allelic } \\
\text { diversity }\end{array}$ & \multicolumn{3}{|c|}{ Test for HWE } \\
\cline { 3 - 8 } & TaqI & 100 & 2 & $\begin{array}{c}0.37 \\
4\end{array}$ & 0.490 & 0.498 & $\begin{array}{c}\text { HWE Chi } \\
\text { square } \\
\text { probability }\end{array}$ & $\begin{array}{c}\text { DF } \\
\text { PhiSq* }\end{array}$ & $\begin{array}{c}\text { Prob** } \\
\text { Exact }\end{array}$ \\
\hline
\end{tabular}

*p-value for the Chi-square test; **an estimate of the exact p-value for the HWE test; HWE=Hardy-Weinberg equilibrium; PIC=Polymorphic information content

Fig.1 Amplification of 285 bp fragment of MHC Class II DRB gene exon 2 in Salem Black goat Lane M: 100 bp DNA marker; Lane 1-8: Amplified products

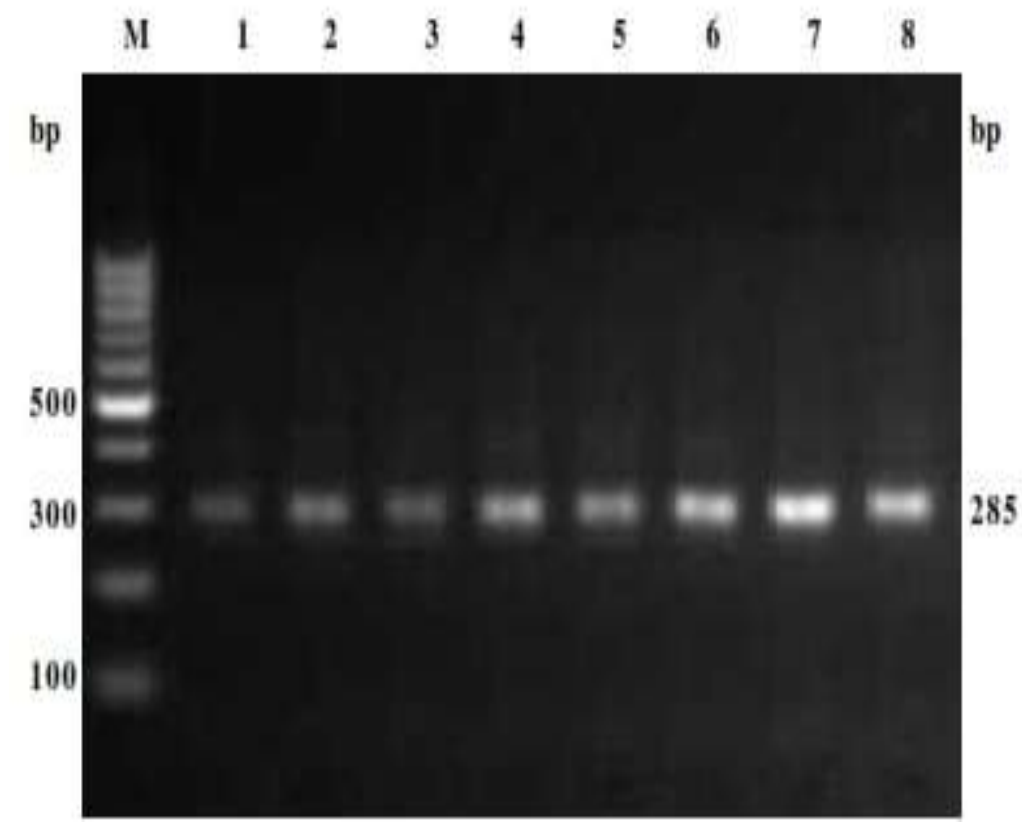


Fig.2 RE digestion of 285 bp fragment of MHC Class II DRB gene exon 2 by TaqI enzyme in Salem Black goat

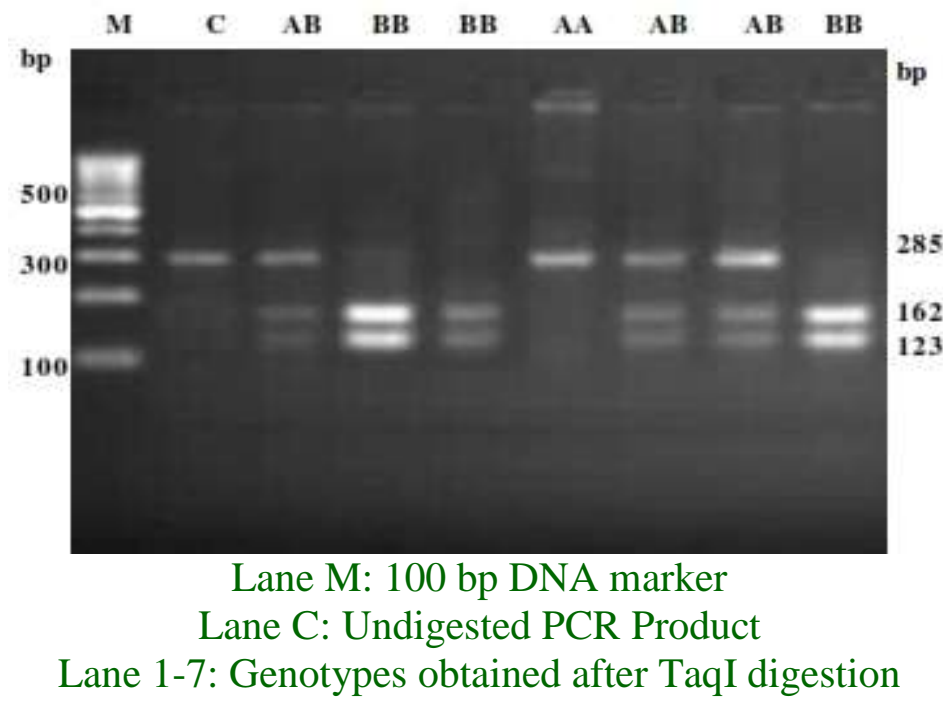

The population genetic analysis of the genotypic data showed loci to be significantly deviating from HWE with more homozygosity, however, earlier PCR RFLP studies on this gene have been reported heterozygote excess and significant deviations from HWE using multiple restriction enzymes (Jamshidi et al., 2011; Gruszczynska et al., 2004). Previous reports have also shown that population that is relatively closed and breeding randomly within the herd tends to be in HWE (Li et al., 2011).

MHC Class II genes are pivotal in conferring resistance/susceptibility to parasitic infestation (Karrow et al., 2014). MHC gene loci polymorphism is one of the major drivers of species survival. The polymorphism was reported in MHC Class II DRB3 gene of Salem black goats by PCR-RFLP technique. The polymorphism of this gene locus has been extensively studied with the association studies and is advocated to be used as a genetic marker for nematode resistance/ susceptibility (Jamshidi et al., 2011). In the current study, the MHC Cass II DRB3 gene was found polymorphic in Salem black goats for TaqI locus. The importance of this fragment is that it forms the part of antigen presentation region of the MHC gene and hence it has much importance for disease resistance research.

\section{Acknowledgments}

The authors are thankful to Director, IVRI, Izatnagar, Bareilly (U.P.) for providing necessary facilities during entire research work at this esteemed deemed university. We are also thankful to Animal Husbandry Department, Tamilnadu for providing assistance during collection of samples. The first author is also thankful to Indian Council of Agricultural Research for providing necessary financial assistance in the form ICAR-JRF during the study

\section{References}

Amills, M., Francino, O. and Sanchez, A. (1990), A PCR-RFLP typing method for the caprine Mhc class II DRB gene, Vet. Immunol. Immunopath., 55: 255-260.

Baghizadeh, A., Bahaaddini, M., Mohamadabadi, M.R. and Askari, N., 2009. Allelic variations in exon 2 of Caprine MHC 
Class II DRB3 Gene in Raeini Cashmere goat. American-Eurasian J. Agric. \& Environ. Sci, 6(4), pp.454-459.

Dukkipati, V.S.R., Blair, H.T., Garrick, D.J. and Murray, A. (2006), 'Ovar-Mhc'- Ovine major histocompatibility complex: Role in genetic resistance to diseases, New Zealand Veterinary Journal, 54(4): 153160.

Garrigan, D., Hedrick, P.W., 2001. Class I MHC polymorphism and evolution in endangered California Chinook and other Pacific salmon. Immunogenetics 53, 483489.

Gruszczynska J, Brokowska K, Charon KM, Swiderek WP. (2004). Restriction fragment length polymorphism of exon 2 Ovar-DRB1 gene in Polish Heath Sheep and Polish Lowland Sheep. J. Appl. Genet. 46: 311-314.

Jamshidi, R., Brujeni, Gh. N., Derakhshandeh, A. and Talebnia, R. (2011), Exon 2 OvarDRB1 gene polymorphism in the Iranian Sangsari sheep, Int. J. Vet. Res., 5(1): 5962.

Karrow, N.A., Goliboski, K., Stonos, N., Schenkel, F. and Peregrine, A. 2014. Review: Genetics of helminth resistance in sheep. Can. J. Anim. Sci., 94: 1-9.

Klein, Jan. Natural history of the major histocompatibility complex. Wiley, 1986.

Li, M.H., Li, K., Kantanen, J., Feng, Z., Fan, B. and Zhao, S.H., 2006. Allelic variations in exon 2 of caprine MHC class II DRB3 gene in Chinese indigenous goats. Small ruminant research, 66(1), pp.236-243.

Li, R.Y., Hui, W.Q., Jia, B., Shi, G.Q., Zhao, Z.S., Shen, H., Peng, Q., Lv, L.M., Zhou, Q.W. and Li, H.T. (2011), The relationship between MHC-DRB1 gene second exon polymorphism and hydatidosis resistance of Chinese merino (Sinkiang Junken type), Kazakh and Duolang sheep, Parasite, 18: 163-169.

Nikbakht Brujeni, G., Emam, M., Mahmoudzadeh, H., Hamedmonfared, E., Talebnia Jahromi, R. and Rezaei, H., 2009. Typing of Ovar-DRB1 second exon with PCRRFLP technique in Iranian Shaul Sheep. Iranian Journal of Veterinary Research, 10(3), pp.250-254.

Prakash O, Kumar P, Shrivastava K, Thirunavukkarasu SB, Sahoo NR, Kumar A, Chauhan A, Bhushan B, Pachaury R, Charan R, Chaudhary R. 2017. Novel Polymorphism at Exon 2 of Caprine MHC Class II DRB3 Gene in Marwari Goats. Journal of Animal Research. 7(4): 623627.

Sambrook, J. and Russell, D.W. 2001. Molecular cloning a laboratory Manual. 3rd Edition. Cold Spring Harbor Laboratory Press, NY, USA.

Shrivastava, K, Kumar, P., Sahoo, N.R., Kumar, A., Khan, M.F., Kumar, A., Prasad, A., Patel, B.H.M., Nasir, A., Bhushan, B., Sharma, D. 2015. Genotyping of major histocompatibility complex Class II DRB gene in Rohilkhandi goats by polymerase chain reaction-restriction fragment length polymorphism and DNA sequencing, Vet. World., 8 (10): 1183-1188.

Takada, T., kikkawa, Y., Yonekawa, H., Amano, T., 1998. Analysis of goat MHC class II DRA and DRB genes identification of the expressed gene and new DRB alleles. Immunogenetics 48, 408-412.

Tizard, I.R. (2004), Veterinary Immunology. $7^{\text {th }}$ edition. Saunders, Philadelphia. Pp: 496.

\section{How to cite this article:}

Thirunavukkarasu, S. B., Pushpendra Kumar, Om Prakash, Amit Kumar, Nihar Ranjan Sahoo, G. V. P. P. S. Ravikumar, Bharat Bhushan, K. Ilayakumar, V. Sharavanan and Nagarajan, N. 2019. Genetic Polymorphism of MHC Class II DRB3 Gene in Salem Black Goats by PCRRFLP. Int.J.Curr.Microbiol.App.Sci. 8(10): 1415-1420.

doi: https://doi.org/10.20546/ijcmas.2019.810.166 